\title{
Post Graduate Student and their Ability of Processing Educational Research Skills from Their Perspective in Jordanian Educational Faculties
}

\author{
Bashar A. AL- Saleem ${ }^{1, *}$, Ahamad M. Badah ${ }^{1}$, Habis S. Al Awamleh ${ }^{1}$ \& Yousra \\ Al- Ali $^{1}$ \\ ${ }^{1}$ Prince Alia Faculty, Al Balqa Applied University, PO Box 969, Irbid, Jordan \\ *Corresponding author: Prince Alia Faculty, Al Balqa Applied University, PO Box 969, Irbid, \\ Jordan Tel: 962-777-215-263 E-mail: bashartlilan@gmail.com
}

Received: January 30, 2013 Accepted: April 11, $2013 \quad$ Published: June 12, 2013

doi:10.5296/ije.v5i2.3183 URL: http://dx.doi.org/10.5296/ije.v5i2.3183

\begin{abstract}
The study aimed at investing the ability extent of post graduate students in education science faculties in Jordan in processing education research from their point of view and the differences between postgraduate student of having such skills due to gender, university, and education degree. The study sample consists of (281) graduate students males and females. To achieve the research objectives the researchers developed a questionnaire of (62) items. SPSS was used to analyze the gathered data.

The study concluded the following results; means indicated that the post graduate students in education science faculties in Jordan don't have, to a great extent, the educational research skills. Results also revealed that there are no statistical differences between the study sample averages due to gender, university, and educational degree.

The researchers recommended more specialized high quality courses to be held for under graduate and post graduate students on the basic skills of educational research.

Keywords: post graduate students; educational research; skills; Jordanian educational faculties
\end{abstract}




\section{Introduction}

Human history never witnessed a similar information revolution that current age have. Information age that we live now is an age of knowledge, scientific specialties, computer, vast development in information storage, retrieve the same and rapid exchange on the world level. The internet is a prominent evidence of information revolution we are witnessing nowadays. Internet is natural result of scientific research progress that is deemed a goal for universities, students and researchers. (Baron and Strout, 2001).

Rapid change in various fields is considered one of the most important new age features, which leads to the necessity of changing corporations' functions regardless of type, shape and size. Education is deemed one of the most important means where public build its human feature, since it is the main base that most or even all states focused on to develop countries. It is well known that education is not anymore a social requirement, it is a need and not a service, it is an investment that has huge return increased by increment of oriented expenditure. ( Bellard, 2007).

Education is not separated from change, it is the bowl which changes channels poured in, and specified in integrated and experiences in educational order, recommended by modern educational methods, and subjected to learner perceptions, and his modern educational technical readiness and new educational methods. Therefore, the big challenge before graduation and work is to cope with these changes which enrich all elements of teaching and learning it needs renewable skills to follow but such skills are not acquired by chance, and couldn't be obtained by studying a program but, it needs comprehensive and complete chain of programs that depend on scientific planning and methodological order linked with daily problems the teacher face in his work (Abuzaid, 2007).

Education research is deemed as a basic mean that attitudes, plans and goals could be achieved through. By carrying out researches in our work and during study we pave the road to form a generation that is characterized by the desired features, or in other words we set the principles of community we look for, therefore educational research is a cornerstone of educational operation pillars.

Because educational researches of its different types are deemed the major source for educational process and its outcomes, developed countries had supported these researches with all available means. Such interest in educational research by developed countries was materialized by supporting educational scientific research through allocating a percentage of its GDP. For example, in 1990 the United States of America spent around 3\% of its natural income on scientific research while European states spent $2.2 \%$ of its natural income (AlSultan. 1993).

Education reform process requires conducting various educational researches for the purpose of scientific treatment of educational issues, in order to discover barriers that impair development in our schools, since school cannot be viewed, it should be viewed with renewable and changeable view lifeless Therefore, educational research is the objective approach to reform and renew educational systems in Arab countries. (Al- Farah, 1985). 
Most educational faculties students work as teachers. Teacher appropriate preparation is one of the factors that assist in educational systems and learning process success in our counties.

Teacher preparation in all fields is deemed a basic factor in society development. Teachers are the main focal party, since they are the basic factor of discovering creativity with students and developing the same to achieve society goals, reform and developing the same (Brew, 2006).

Live excretions in all kinds lead to create many educational problems that make post graduate students unable to find the appropriate solutions for it, but through educational research solution, responses and alternatives that assist teachers in deepening their understanding for such issues and different dimensions of educational process and problems, difficulties if faces can be found. Educational research is the only approach that help us to find us to find the best approaches that enable us to develop the two aspects, the qualities and quantities in the educational process and its outcomes. Therefore, post graduate students' ability of processing educational research and reviewing educational studies and researches and pay attention that it deserves is a basic request for them to reach effective teaching and right educational decision.

Shatat (1995) claimed the necessity of postgraduate students training on educational research skills to be able to solve educational problems he faces taking in consideration that school is a real lab of education and teacher will not be qualified unless he acquires the competences related to preparation of methodological educational researches.

The superior goal of educational research is to find the new knowledge through providing solutions and alternatives that enable us in deepening our understanding of different dimensions of educational process and its problems. It also assists in activating our educational establishments and renewing live in it, and in its programs, teachers, activities, methods, and curriculums. Educational research importance recognition means the realization of educational renew importance in general, which means it should be a main starting point for educational polices in our countries and important pillar. (Mursi, 1994).

Perfect educational research starts with a problem or issue that bother the researcher and interested in, then push him to think deeply in its roots and theoretical basis and thinking background that contribute in phenomenon classification and facts interpretation (Hughes, 2005).

Many studies have been made which confirm the educational researches importance and its role in improving teaching process. Many researchers are interested in educational research either in universities, ministries or private corporations.

$\mathrm{Al}$-Farah (1985) study aimed at investigating the scientific research role in education field in reforming process, and modernizing education systems in Arab countries. The study used the documentation methodology approach. The study concluded many results, among them are the following:

1) Many educational researches are conducting for the purpose of achieving formalism purpose not for treating real problems that face decisions making and important in 
educational process development.

2) Most of educational researches are conducting in the absence of complete and comprehensive plan.

Lampert (1988) study focused on educational research role in improving mathematics teaching and raising teachers level. The researcher concluded that teachers preparation programs should depend on educational researches results.

Sultan (1993) study aimed at investigating the scientific research status in Kuwait and its role in improving the academic curriculum development. The study concluded that scientific research has significant role in developing teachers and learners' abilities on innovation scientific thinking.

Berlin (1996) study discussed the impact of investigation research in developing official curriculums. The study concluded that education researches support teacher's role in improving implementation and evaluation process inside the academic class through providing them with knowledge, and experience derived from researches results.

Hammond (1998) study concluded that teachers who know a lot about education through reading and reveling education researches results are those which are living closely in teaching environment that enable them to know the students and their education problems are the most successful teachers in their work.

Husen (1994) study confirmed that there is a huge amount of education researches results related to education problems, because education research success in the field requires that its results should be communicated to two types of professionals associated education process such as planners, and executers and they are the education policy makers and the executer of such policy of teachers, schools' principles and education supervisors.

Sands (2009) performed a study aimed at exploring the obstacles of scientific research. The sample consist of (400) male and female students, who were subject to the study instrument, which involved (33)I items. The results indicated that the students lack the research procedures, the motives to conduct research, and the financial support to science, library, and completer labs. The study recommended to increase the financial support to research as well as training students on research skills.

Al-shboul (2009) study aimed to expose the attitudes of secondary schools principals in Jordan towards educational research and it is outcomes. A questioner had been distributed among a sample of (225) principals. A number of results were induced after establishing the medium and derivational average: first there were no significant differences in the importance, method, and merits of the research, but there were significant differences in the outcomes of the research regarding gender. Second there were significant differences in the importance, method, and merits of the research, but there were no significant differences in the outcomes of the research regarding qualification and administrative expedients. Third there were significant differences between those who obtained B.A. and higher diploma and those who obtained Ph.D., the difference was to the benefit of the Ph.D. holders. 
Based on the above previous studies, it is obvious that all of which approximately agreed on the importance of education research, and that if one of the assistant tools of improving education process. It can be noticed that some of these studies focused on specific subjects in education research such as the relation between education research and decision making size, moreover most of previous studies tend to education theorizing more than the implementation. The current study is distinguished in investigating the opinions of the concerned in the education process namely teachers, secondary stage teachers in particular, which gives this study a scientific value, and it will investigate the teachers acquisition degree of education research skills and its relation with some variable such as gender, education level, experience in teaching and the subjects he teaches. Furthermore, this study will use the survey methodology at investigating status teachers ability of education research results.

\section{Method and Procedures}

The methodology: the researchers adopted the descriptive methodology, as they used a survey to assess the attitudes of students towards the use of information and communication technologies.

\subsection{Questions of the Study}

The following are sub-questions that are derived from the main one above:

- What is the degree of educational research skills that the graduate students in education science faculties in Jordan from their point of view?

- Are there statistically significant differences at the level of statistical significance $(\alpha=$ 0.05 ) between the averages of the estimates of graduate students in the education science faculties in Jordan on the instrument exercising the skills of educational research due to the variable (gender, university, and education degree) and the interaction between them?

\subsection{Objectives of the Study}

The main aim of this education research is a contribution attempt in developing and improving education process hoping to solve its problems. We can by education research give clear predictions regarding education actual route, and its extent in achieving the plans that already drawn. Education researches do help in achieving its main task as in the case of other research, among it revealing the problem and cases that need study research and raising and increasing scientific knowledge and assisting on future predicting. It is clear from these jobs the importance of teachers ability of processing education research skills. This research is deemed the first study on the Arab and local level, since the two researchers don't find upon their best knowledge any study in this field, in addition to lack of studies and researches in general and Jordanian ones in particular, regarding teachers ability of processing education research skills. The results of this study may have the impact in directing these who are in charge of education process in Jordan to benefit from study tool which is characterized with validity and reliability and easy use of its results, and also this study is expected to contribute 
in encouraging researcher to start in conducting more studies and similar field researches to know teacher acquisition degree of education research.

\subsection{Terms used in the Study}

The following terms and concepts, presented in this study, mean the explanations that are shown below:

- Education research: Al Nouri (1982) defined education research as the activity that aims to provide knowledge that allows teachers to achieve education aims with most effective methods and means. This is made by studying student environment and makes to develop the desired attitude in growth and enhance it as much as possible.

- Skills: refer to a set of abilities the teachers has and practice to enable him to perform his teaching duties effectively.

\subsection{Limitation of the Study}

There are many limitations that may reduce the possibility of generalization study results outside study population such as:

1) The study is restricted on that the graduate students in education science faculties in Jordan.

2) The study is restricted on educational research skills listed on the study tool prepared by the researchers.

\subsection{Community of the Study and the Sample}

The study population was the total number of graduate students in education science faculties in Jordan(5726) students, (3721) males and (2005). The researchers select the study sample randomly, the selection percent is more than of the total that the graduate students in education science faculties in Jordan. The sample size was (218) students, (128) males and (90) were females.

\subsection{Research Instrument}

The researchers develop a questionnaire for the purpose of the current study to measure the degree of educational research skills that the graduate students in education science faculties in Jordan from their point of view.

\subsection{Statistical Treatment}

To answer the study questions the use of statistical treatments were as follows:

- Arithmetic means and standard deviations.

- Three-way analysis of variance (Three Way ANOVA).

\subsection{Statistical Standard}

To explain the arithmetic averages of the estimates of a sample of graduate students in the 
colleges of Education in Jordan (students) on each paragraph of the tool, the use of standard statistical follows:

From 1.00 - less than 1.80

From 1.80 - less than 2.60

From 2.60 - less than 3.40

From 3.40 - less than 4.20

From 4.20 - less than 5.00 very low

low degree

Medium degree

high degree

very high

\section{Results and Discussion of the Study}

\subsection{Results and Discussion of the First Question, Which Is}

"What is the degree of educational research skills that the graduate students in education science faculties in Jordan from their point of view?"

To answer this question averages and standard deviations for the estimates of a sample of graduate students in the education science faculties in Jordan on the paragraphs of the tool and as a whole and to the paragraphs relating to the exercise of skills, educational research, have been calculated and Table (1) shows that.

Table 1: Arithmetic means and standard deviations for the estimates of a sample of graduate students in education science faculties in Jordan on the paragraphs of the tool and as a whole and to the paragraphs relating to the exercise of educational research skills arranged in descending order according to averages

\begin{tabular}{|c|c|c|c|c|c|}
\hline $\begin{array}{l}\text { Paragraph } \\
\text { number }\end{array}$ & Rank & Paragraph & means & $\begin{array}{l}\text { standard } \\
\text { deviations }\end{array}$ & Estimate \\
\hline 8 & 1 & $\begin{array}{l}\text { Justify your choice for the } \\
\text { problem of the study. }\end{array}$ & 2.33 & 0.95 & Low \\
\hline 4 & 2 & $\begin{array}{l}\text { Take into account in the selection } \\
\text { of subject and the abundance of } \\
\text { its substance and its sources and } \\
\text { the need for it. }\end{array}$ & 2.19 & 0.86 & Low \\
\hline 45 & 3 & $\begin{array}{l}\text { Reveal the source of the } \\
\text { differences between the averages } \\
\text { in the different groups. }\end{array}$ & 2.18 & 1.04 & Low \\
\hline 2 & 4 & $\begin{array}{l}\text { Choose a research topic in line } \\
\text { with the tastes and } \\
\text { commensurate with Your major. }\end{array}$ & 2.17 & 0.89 & Low \\
\hline 61 & 5 & $\begin{array}{l}\text { You can discuss the results in } \\
\text { light of the characteristics of the } \\
\text { target group }\end{array}$ & 2.16 & 1.25 & Low \\
\hline 1 & 6 & $\begin{array}{l}\text { Choose specifically the address } \\
\text { to include the main study } \\
\text { variables }\end{array}$ & 2.12 & 1.03 & Low \\
\hline
\end{tabular}




\begin{tabular}{|c|c|c|c|c|c|}
\hline 3 & 7 & $\begin{array}{l}\text { Gathering the necessary } \\
\text { information and scientific facts } \\
\text { about the problem the previous } \\
\text { question. }\end{array}$ & 2.12 & 0.98 & Low \\
\hline 19 & 8 & $\begin{array}{l}\text { Invest the information from } \\
\text { previous studies }\end{array}$ & 2.12 & 0.91 & Low \\
\hline 53 & 9 & $\begin{array}{l}\text { Looking for possible effects of } \\
\text { the variables that are not tuned to } \\
\text { results }\end{array}$ & 2.12 & 1.19 & Low \\
\hline 62 & 10 & $\begin{array}{l}\text { Make recommendations to } \\
\text { complete the study of the subject } \\
\text { that did not target your studies }\end{array}$ & 2.12 & 0.96 & Low \\
\hline 33 & 11 & $\begin{array}{l}\text { Describe steps of preparing each } \\
\text { tool of the study }\end{array}$ & 2.11 & 1.00 & Low \\
\hline 26 & 12 & $\begin{array}{l}\text { determine the appropriate way to } \\
\text { choose the representative sample } \\
\text { of the population }\end{array}$ & 2.10 & 0.81 & Low \\
\hline 10 & 13 & $\begin{array}{l}\text { Benefit from the } \\
\text { recommendations of previous } \\
\text { studies to determine the problem }\end{array}$ & 2.06 & 0.93 & Low \\
\hline 23 & 14 & $\begin{array}{l}\text { Link your study with previous } \\
\text { studies }\end{array}$ & 2.06 & 0.87 & Low \\
\hline 27 & 15 & $\begin{array}{l}\text { Determine the appropriate size of } \\
\text { the sample }\end{array}$ & 2.04 & 0.99 & Low \\
\hline 12 & 16 & $\begin{array}{l}\text { Set targets that are achievable } \\
\text { with given time and effort of the } \\
\text { search. }\end{array}$ & 2.03 & 0.85 & Low \\
\hline 54 & 16 & $\begin{array}{l}\text { Develop recommendations for } \\
\text { future research depending on } \\
\text { the results }\end{array}$ & 2.03 & 0.73 & Low \\
\hline 16 & 18 & $\begin{array}{l}\text { Identify relevant studies the } \\
\text { problem of research to be } \\
\text { conducted. }\end{array}$ & 2.00 & 0.92 & Low \\
\hline 11 & 19 & $\begin{array}{l}\text { You can formulate procedural } \\
\text { definitions of concepts are }\end{array}$ & 1.99 & 0.87 & Low \\
\hline 25 & 19 & $\begin{array}{l}\text { Distinguish between probability } \\
\text { samples and non-probability } \\
\text { samples. }\end{array}$ & 1.99 & 0.76 & Low \\
\hline 9 & 21 & $\begin{array}{l}\text { Determine who will benefit from } \\
\text { the research. }\end{array}$ & 1.97 & 0.80 & Low \\
\hline 28 & 21 & $\begin{array}{l}\text { Determine the characteristics of } \\
\text { the required data from the } \\
\text { sample. }\end{array}$ & 1.97 & 0.87 & Low \\
\hline 18 & 23 & $\begin{array}{l}\text { Derive the relationship between } \\
\text { the problem set by the previous } \\
\text { studies. }\end{array}$ & 1.96 & 0.88 & Low \\
\hline 32 & 24 & $\begin{array}{l}\text { You can choose the appropriate } \\
\text { way to ensure the stability of the } \\
\text { study tools }\end{array}$ & 1.95 & 0.96 & Low \\
\hline 56 & 25 & $\begin{array}{l}\text { Pose problems in other research } \\
\text { study }\end{array}$ & 1.94 & 0.72 & Low \\
\hline
\end{tabular}




\begin{tabular}{|c|c|c|c|c|c|}
\hline 50 & 26 & $\begin{array}{l}\text { To reach conclusions and } \\
\text { solutions based on the analysis of } \\
\text { the data. }\end{array}$ & 1.92 & 0.76 & Low \\
\hline 5 & 27 & $\begin{array}{l}\text { You can formulate the problem } \\
\text { in a specific and clear. }\end{array}$ & 1.91 & 0.94 & Low \\
\hline 21 & 28 & $\begin{array}{l}\text { Previous studies classified axes } \\
\text { consistent with the purpose of } \\
\text { the study. }\end{array}$ & 1.90 & 0.73 & Low \\
\hline 6 & 29 & $\begin{array}{l}\text { You can formulate the study } \\
\text { questions in a clear and specific. }\end{array}$ & 1.89 & 0.86 & Low \\
\hline 37 & 29 & $\begin{array}{l}\text { Distinguish between the methods } \\
\text { used to control internal and } \\
\text { external factors }\end{array}$ & 1.89 & 0.91 & Low \\
\hline 43 & 29 & $\begin{array}{l}\text { Was the initial set of data in } \\
\text { multiple ways such as tables. }\end{array}$ & 1.89 & 0.79 & Low \\
\hline 57 & 29 & $\begin{array}{l}\text { Provides an analytical overview } \\
\text { of the critical findings in the } \\
\text { light of their design and their } \\
\text { determinants }\end{array}$ & 1.89 & 0.88 & Low \\
\hline 49 & 33 & $\begin{array}{l}\text { Results are presented in a clear } \\
\text { and precise way }\end{array}$ & 1.88 & 0.89 & Low \\
\hline 55 & 34 & $\begin{array}{l}\text { Linking the results of the study } \\
\text { dimensions of educational }\end{array}$ & 1.87 & 0.79 & Low \\
\hline 15 & 35 & $\begin{array}{l}\text { You can formulate the problem } \\
\text { in a specific and clear. }\end{array}$ & 1.85 & 0.83 & Low \\
\hline 34 & 36 & $\begin{array}{l}\text { Choose the appropriate statistical } \\
\text { tools }\end{array}$ & 1.84 & 0.92 & Low \\
\hline 35 & 37 & $\begin{array}{l}\text { Distinguish between independent } \\
\text { variables and dependent } \\
\text { variables }\end{array}$ & 1.83 & 0.89 & Low \\
\hline 58 & 37 & $\begin{array}{l}\text { You may discuss the results in } \\
\text { light of the nature of the topic or } \\
\text { subject }\end{array}$ & 1.83 & 0.78 & Low \\
\hline 24 & 39 & $\begin{array}{l}\text { Determine the proper } \\
\text { methodology for conducting the } \\
\text { study }\end{array}$ & 1.81 & 0.97 & Low \\
\hline 42 & 39 & $\begin{array}{l}\text { Calculated the correlation } \\
\text { coefficient between variables at } \\
\text { different levels of measurement. }\end{array}$ & 1.81 & 0.91 & Low \\
\hline 39 & 41 & $\begin{array}{l}\text { Transformation of raw marks to } \\
\text { graphic images. }\end{array}$ & 1.78 & 0.74 & Very low \\
\hline 48 & 41 & $\begin{array}{l}\text { The results of examination of } \\
\text { each hypothesis or question } \\
\text { separately }\end{array}$ & 1.78 & 0.78 & Very low \\
\hline 60 & 41 & $\begin{array}{l}\text { Provide guidance associated with } \\
\text { the actual results of the study }\end{array}$ & 1.78 & 0.75 & Very low \\
\hline 14 & 44 & $\begin{array}{l}\text { You can formulate testable } \\
\text { hypotheses }\end{array}$ & 1.77 & 0.81 & Very low \\
\hline 41 & 45 & $\begin{array}{l}\text { Choose the appropriate measure } \\
\text { for the analysis of statistical data }\end{array}$ & 1.77 & 0.77 & Very low \\
\hline 7 & 46 & You can specify the objective of & 1.76 & 0.72 & Very low \\
\hline
\end{tabular}


the research problem clearly and accurately.

\begin{tabular}{|c|c|c|c|c|c|}
\hline 17 & 47 & $\begin{array}{l}\text { Benefit from previous studies in } \\
\text { procedures }\end{array}$ & 1.75 & 0.72 & Very low \\
\hline 40 & 48 & $\begin{array}{l}\text { You answer the study questions } \\
\text { and test hypotheses that you use. }\end{array}$ & 1.74 & 0.77 & Very low \\
\hline 52 & 48 & $\begin{array}{l}\text { Linking educational literature } \\
\text { discussing the results in terms of } \\
\text { compatibility and incompatibility }\end{array}$ & 1.74 & 0.74 & Very low \\
\hline 59 & 50 & $\begin{array}{l}\text { You may provide rationale for } \\
\text { the ideas contained in the } \\
\text { discussion }\end{array}$ & 1.73 & 0.86 & Very low \\
\hline 20 & 51 & $\begin{array}{l}\text { You can design and use of study } \\
\text { tools. }\end{array}$ & 1.71 & 0.78 & Very low \\
\hline 38 & 52 & $\begin{array}{l}\text { Distinguish between variables } \\
\text { and the exact modified and } \\
\text { exotic. }\end{array}$ & 1.69 & 0.75 & Very low \\
\hline 51 & 52 & $\begin{array}{l}\text { You can discuss each question } \\
\text { separately }\end{array}$ & 1.69 & 0.76 & Very low \\
\hline 30 & 54 & $\begin{array}{l}\text { You can design and use of study } \\
\text { tools. }\end{array}$ & 1.68 & 0.74 & Very low \\
\hline 29 & 55 & $\begin{array}{l}\text { Describes the size and } \\
\text { characteristics of the society in } \\
\text { which it conducted the study. }\end{array}$ & 1.67 & 0.70 & Very low \\
\hline 46 & 56 & $\begin{array}{l}\text { Gives descriptive statistics } \\
\text { appropriate for the study. }\end{array}$ & 1.65 & 0.72 & Very low \\
\hline 31 & 57 & $\begin{array}{l}\text { You can choose the appropriate } \\
\text { way to make sure the } \\
\text { psychometric properties of study } \\
\text { tools. }\end{array}$ & 1.64 & 0.74 & Very low \\
\hline 44 & 57 & $\begin{array}{l}\text { Adoption of the distribution } \\
\text { histogram for a set of data and } \\
\text { graphically display the } \\
\text { distribution }\end{array}$ & 1.64 & 0.81 & Very low \\
\hline 22 & 59 & $\begin{array}{l}\text { Identify the main references in } \\
\text { the studies that you want to use }\end{array}$ & 1.60 & 0.77 & Very low \\
\hline 36 & 60 & $\begin{array}{l}\text { The procedures of application of } \\
\text { the study accurately }\end{array}$ & 1.57 & 0.74 & Very low \\
\hline 13 & 61 & $\begin{array}{l}\text { You can formulate hypotheses } \\
\text { derived from the study questions } \\
\text { in an orderly and carefully way }\end{array}$ & 1.55 & 0.64 & Very low \\
\hline 47 & 62 & $\begin{array}{l}\text { Determine the level of the user } \\
\text { before you start analyzing the } \\
\text { results. }\end{array}$ & 1.54 & 0.64 & Very low \\
\hline
\end{tabular}

As seen from table (1) graduate students in the faculties of Education Sciences practice skills of educational research were low, arithmetic average of (1.89) standard deviation (0.41). Ranged their estimates on the paragraphs of the instrument between (1.45) and (2.33) and the degree of estimation ranged between (very low) and (low), a paragraph (8) came in the first place with an average arithmetic (2.33) standard deviation (0.95) and the degree of estimation is low. While paragraph (47) ranked last arithmetic average of (1.45) standard deviation (0.64) 
and estimate the degree is very low. This may be attributed to graduate students not perception education research value and its role in improving learning and teaching process. It also can be attributed to under graduate stage nature which doesn't assure research importance through the existing activities in curriculum and the lake in this stage researches writing through reviewing specialized fields. Also the graduate students are unable to select educational researches that agree with their attitudes and activity.

\subsection{Results and Discussion of the Second Question, Which Is}

"Are there statistically significant differences at the level of statistical significance $(\alpha=0.05)$ between the averages of the estimates of graduate students in the colleges of Education in Jordan on the instrument exercising the skills of educational research due to the variable (gender, university, and education degree ) and the interaction between them?

To answer this question have been calculated averages and standard deviations for the estimates of a sample of graduate students in the colleges of Education in Jordan on the paragraphs of the instrument exercising the skills of educational research as a whole and by variable (gender, university, and education degree), and Table (2) shows that.

Table 2: Arithmetic means and standard deviations for the estimates of graduate students on the instrument exercising the paragraphs of the skills of educational research as a whole and by variable (gender, university, and educational degree)

\begin{tabular}{lllllllllll}
\hline University & $\begin{array}{l}\text { Education } \\
\text { al degree }\end{array}$ & \multicolumn{3}{c}{ Gender } & \multicolumn{3}{c}{ Total } \\
\cline { 3 - 12 } & & Male & \multicolumn{3}{c}{ Female } \\
\cline { 3 - 12 } Governmental & Ph.D & 33 & 1.96 & 0.45 & 25 & 1.78 & 0.33 & 58 & 1.88 & 0.41 \\
& Master & 50 & 1.91 & 0.51 & 34 & 1.83 & 0.25 & 84 & 1.88 & 0.42 \\
& Total & 83 & 1.93 & 0.48 & 59 & 1.81 & 0.28 & 142 & 1.88 & 0.41 \\
Private & Ph.D & 19 & 2.03 & 0.40 & 15 & 1.88 & 0.50 & 34 & 1.97 & 0.44 \\
& Master & 26 & 1.87 & 0.46 & 16 & 1.82 & 0.22 & 42 & 1.85 & 0.38 \\
\multirow{5}{*}{ Total } & Total & 45 & 1.94 & 0.44 & 31 & 1.85 & 0.37 & 76 & 1.90 & 0.41 \\
& Ph.D & 52 & 1.98 & 0.43 & 40 & 1.82 & 0.40 & 92 & 1.91 & 0.42 \\
& Master & 76 & 1.89 & 0.49 & 50 & 1.83 & 0.24 & 126 & 1.87 & 0.41 \\
& Total & 128 & 1.93 & 0.46 & 90 & 1.82 & 0.32 & 218 & 1.89 & 0.41 \\
\hline
\end{tabular}

As seen from table (2) there are apparent differences between the averages of the estimates of a sample of graduate students in the colleges of Education in Jordan to instrument paragraphs for exercising skills of educational research as a whole and by variable (gender, university, and educational degree), and to find out statistical significance of these differences virtual; been the use of three-way analysis of variance (Three Way ANOVA), and Table (3) shows that. 
Table 3: The results of analysis of variance of the averages of three estimates for the graduate students on the instrument exercising the paragraphs of the skills of educational research as a whole and by variable (gender, university, and educational degree) and the interaction between them

\begin{tabular}{llllll}
\hline Source & $\begin{array}{l}\text { Sum of } \\
\text { square }\end{array}$ & Df & $\begin{array}{l}\text { Mean } \\
\text { square }\end{array}$ & $F$ & Significant \\
\hline Gender & 0.950 & 1 & 0.950 & 3.462 & 0.064 \\
University & 0.049 & 1 & 0.049 & 0.290 & 0.591 \\
Educational degree & 0.148 & 1 & 0.148 & 0.866 & 0.353 \\
Gender* university & 0.011 & 1 & 0.011 & 0.065 & 0.799 \\
Gender* educational degree & 0.120 & 1 & 0.120 & 0.702 & 0.403 \\
University* Educational degree & 0.150 & 1 & 0.150 & 0.880 & 0.349 \\
Gender*University* Educational degree & 0.000 & 1 & 0.000 & 0.001 & 0.982 \\
Error & 35.771 & 210 & 0.170 & & \\
Total & 36.838 & 217 & & & \\
\hline
\end{tabular}

Statistically significant at the level of statistical significance $(\alpha=0.05)$.

As seen from table (5) there is no statistically significant difference at the level of statistical significance $(\alpha=0.05)$ between the intermediate actuarial estimates of a sample of graduate students in the colleges of Education in Jordan on the paragraphs of the instrument exercising the skills of educational research as a whole due to the variable of gender, university, educational degree, and the interact and agreement ions among them, where the values of statistical significance is greater than the level of statistical significance $(\alpha=0.05)$. This can be attributed that both male and female graduate students don't have a complete belief of education research importance and its value in enhancing the work and that whatever was the university or the education degree the education research skills are owned by experience and agreement and homogenous in their skill acquisition degree.

\section{Recommendations}

1) Qualitative training courses in education research skills should be included in the post graduate curriculums.

2) Students should be accepted for Post graduate programs according to their interest and experiences not according to their grades.

3) Students should pay attention to education research basic skills and employ it in learning process.

4) Conducting depth and specialized courses for post graduate students regarding methodology, statistics and statistical analysis.

5) Conducting more similar studies on other colleges on Jordanian universities. 


\section{References}

Abuzaid, A., \& Ibrahim, M. (2007). Educational Research Skills. (1 ${ }^{\text {st }}$ ed). Amman: DarAlfiker. P67.

Al- Farah, W. (1985). Education research and education decision-making. ( $\left.2^{\text {nd }} \mathrm{ed}\right)$. Amman: Dar Al- Manhal for publishing and distribution. P.45.

AL-Shboul, M. (2009). Attitudes of secondary school principals in Jordan towards the educational research and its outcome. Dirasat, Educational Sciences, 36(1), 20-35.

Al-Sultan, Y. (1993). The role of academic curriculums in developing scientific research. Education magazine, 4(11), 25-33.

Baron, S., \& Strout, A. (2001). Communicating with and empowering international students with a library skills set. Reference Services Review, 29(4), 314-326. http://dx.doi.org/10.1108/00907320110408447

Bellard, E. M. (2007). Information literacy needs of nontraditional graduate students in social work. Research $\quad$ Strategies, 20(4), 494-505. http://dx.doi.org/10.1016/j.resstr.2006.12.019

Berlin, D.F. (1996). Teacher Action Research: The Impact Of Inquiry On Curriculum Improvement And Professional Development. (New York, NY. April 8/12/1996 Columbus, OH: National Center For Science Teaching And Learning (ERIC Document Reproduction Service No, ED397-029).

Brew, A. (2006). Research and teaching: Beyond the divide. ( $2^{\text {nd }}$ ed). New York: Palgrave Macmillan. P.65.

Hammond, L. (1988). Teachers And Teaching: Testing Policy Hypothesis From A National Commission Report. Educational Research, 27(1), 5-14.

Hughes, H. (2005). Actions and reactions: exploring international students' use of online information resources. Australian Academic \& Research Libraries, 36(4), 169-179.

Husen, T. (1994). Educational Research And Policy Making. Educational Research, Methodology, And Measurement, on International Handbook. Edited By John P Keeves Pergeman Press, New York.

Lamert, M. (1988). What Can Research On Teacher Tell Us About Improving Quality In Mathematics Education. Teaching and Teacher Education, 4(2), 157-170. http://dx.doi.org/10.1016/0742-051X(88)90015-7

Mursi, M. (1994). Education research and how we can understand it. (1 ${ }^{\text {st }}$ ed). Cairo:Dar Al-Kutub. P.654.

Sand, A. (2009). The Obstacles of Scientific Research, According to Student of Private schools in Amman. Journal of Education, 5(6), 21-88.

Shatat, Y. (1995). Education research: its importance for teacher and school and its 
preparation method. Al- Tarbia, 26(128), 78-90.

\section{Copyright Disclaimer}

Copyright reserved by the author(s).

This article is an open-access article distributed under the terms and conditions of the Creative Commons Attribution license (http://creativecommons.org/licenses/by/3.0/). 